\title{
Optimization of lipase production using fungal isolates from oily residues
}

\author{
Leticia Miranda Cesário ${ }^{1}$, Giovanna Pinto Pires ${ }^{1}$, Rafael Freitas Santos Pereira ${ }^{1}$, Elisabete Fantuzzi ${ }^{1}$, \\ André da Silva Xavier ${ }^{1}$, Servio Tulio Alves Cassini ${ }^{2}$ and Jairo Pinto de Oliveira ${ }^{3^{*}}$
}

\begin{abstract}
Lipases are triacylglycerol hydrolases that catalyze hydrolysis, esterification, interesterification, and transesterification reactions. These enzymes are targets of several industrial and biotech applications, such as catalysts, detergent production, food, biofuels, wastewater treatment, and others. Microbial enzymes are preferable for large scale production due to ease of production and extraction. Several studies have reported that lipases from filamentous fungi are predominantly extracellular and highly active. However, there are many factors that interfere with enzyme production ( $\mathrm{pH}$, temperature, medium composition, agitation, aeration, inducer type, and concentration, etc.), making control difficult and burdening the process. This work aimed to optimize the lipase production of four fungal isolates from oily residues (Penicillium sp., Aspergillus niger, Aspergillus sp., and Aspergillus sp.). The lipase-producing fungi isolates were morphologically characterized by optical and scanning electron microscopy. The optimal lipase production time curve was previously determined, and the response variable used was the amount of total protein in the medium after cultivation by submerged fermentation. A complete factorial design $3^{2}$ was performed, evaluating the temperatures $\left(28^{\circ} \mathrm{C}, 32^{\circ} \mathrm{C}\right.$, and $\left.36^{\circ} \mathrm{C}\right)$ and soybean oil inducer concentration $(2 \%, 6 \%$, and $10 \%)$. Each lipase-producing isolate reacted differently to the conditions tested, the Aspergillus sp. F18 reached maximum lipase production, compared to others, under conditions of $32^{\circ} \mathrm{C}$ and $2 \%$ of oil with a yield of $11,007\left(\mu \mathrm{g} \mathrm{mL}{ }^{-1}\right)$. Penicillium sp. F04 achieved better results at $36^{\circ} \mathrm{C}$ and $6 \%$ oil, although for Aspergillus niger F16 was at $36^{\circ} \mathrm{C}$ and $10 \%$ oil and Aspergillus sp. F21 at $32{ }^{\circ} \mathrm{C}$ and $2 \%$ oil. These results show that microorganisms isolated from oily residues derived from environmental sanitation can be a promising alternative for the large-scale production of lipases.
\end{abstract}

Keywords: Fungal lipases, Optimization, Factorial design, Oily waste

\footnotetext{
*Correspondence: jairo.oliveira@ufes.br

${ }^{3}$ Federal University of Espírito Santo, Av. Marechal Campos1468, Vitória,

ES 29040-090, Brazil

Full list of author information is available at the end of the article
} original author(s) and the source, provide a link to the Creative Commons licence, and indicate if changes were made. The images or other third party material in this article are included in the article's Creative Commons licence, unless indicated otherwise in a credit line to the material. If material is not included in the article's Creative Commons licence and your intended use is not permitted by statutory regulation or exceeds the permitted use, you will need to obtain permission directly from the copyright holder. To view a copy of this licence, visit http://creativecommons.org/licenses/by/4.0/. The Creative Commons Public Domain Dedication waiver (http://creativecommons.org/publicdomain/zero/1.0/) applies to the data made available in this article, unless otherwise stated in a credit line to the data. 


\section{Graphical Abstract}

\section{Optimization of lipase production using fungal isolates from oily residues}

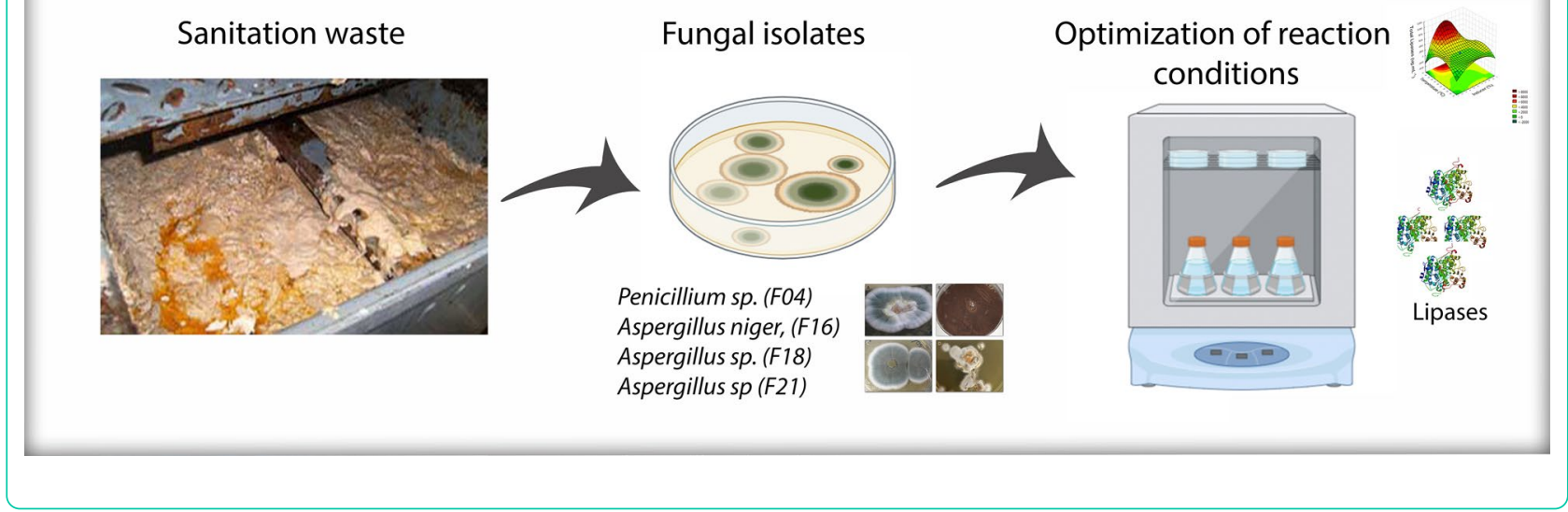

\section{Introduction}

The enzymatic process is only one field among many more in biotechnology, although it has wide applications that are often promising alternatives when it comes to replacing conventional methodologies [1]. The employment of enzymes as biocatalysts improves the processes of production by reducing both energy and raw material costs besides generating fewer toxic residues-circumstances that are in alignment with the principles of green chemistry [2, 3]. Lipases (triacylglycerol acyl-hydrolases, EC 3.1.1.3) are enzymes with a natural role of hydrolyzing triacylglycerol (TAG) into glycerol and free fatty acids, as well as catalyzing the esterification and transesterification reactions $[4,5]$. These very same enzymes play an important role in the degradation of natural materials, industrial pollutants, and other toxic products, due to two of their properties: regioselectivity and enantioselectivity [5]. For this reason, they have a potential application in the agriculture, food, detergent, leather, paper, and pharmaceutical industries [6-9].

From an economic and industrial standpoint, lipases obtained from microorganisms through the fermentation process are preferable over their animal and plant counterparts [10], given both its high yield in a relatively short amount of time and the lower costs associated with the raw materials [11]. Another economic impact is that Brazil has great potential for enzyme production because of its great biodiversity of producing organisms, even though clearly spending more on imported products [12].

Microorganisms produce extracellular lipases to hydrolyze the triglycerides in the medium, facilitating the lipid intake. The expression of microbial lipases is modulated mainly by environmental factors, such as extracellular response to a medium deprived of nutrients, variations in temperature, concentration of inductors etc. The presence of lipids and fatty acids as carbon sources induces the production of these extracellular enzymes. Microorganisms are the most interesting model for protein production, because together the repertoire of regulatory genes and constitutive promoters can be explored in the fermentation process $[13,14]$.

The filamentous fungi and yeasts are preferable lipase sources for commercial use because their lipases usually are part of the extracellular metabolism, which favors their extraction from the fermented medium. Another advantage is that the lipolytic fungi are considered, though not without its exceptions, to be safe microorganisms to manipulate. Apart from the increasing expectation of their application in the shape of immobilized integral lipolytic cells for reactional processes $[15,16]$, alternative species with potential for lipase production mostly described in the literature belong to the genera Rhizopus sp., Mucor sp., Geotrichum sp., Penicillium sp. and Aspergillus sp. [17, 18].

Currently, the heterologous expression of coding genes is used to increase the production of lipases [19]. While this method considerably speeds-up the production of enzymes, the use of genetically modified organisms requires preparations that are not necessary for native systems. Also, in view of industrial-scale production, any surplus, such as excess nutrients and waste make the final product more expensive. With this being said, this work had as its main objective the optimization of production of lipases aiming at sustainable alternatives for the production of lipases on a large-scale A full factorial design was used to optimize the reaction conditions. The 
variables evaluated were temperature $\left({ }^{\circ} \mathrm{C}\right)$ and inducer concentration (\%), and the experiments were carried out by submerged fermentation with 4 fungal isolates from oily residues from environmental sanitation (Penicillium sp. F04, Aspergillus niger (F16), Aspergillus sp. F18, Aspergillus sp. F21).

\section{Metodhology \\ Materials}

The reagents used in the development of this work are as follows: sodium acetate (Proquimios 99\%), hydrochloric acid (Sciavicco, 37\%), bovine serum albumin, BSA (Sigma Aldrich, 98\%), potato dextrose agar, PDA (Acumedia, $100 \%$ ), calcium chloride (Proquimios, 96\%), sodium chloride (Dinâmica, 99\%), commercial virgin soy oil (Liza, Cargill), glutaraldehyde (Sigma Aldrich, 25\%), paraformaldehyde (Sigma Aldrich, 98\%), monobasic sodium phosphate (VETEC, 99\%), bibasic sodium phosphate (VETEC, 99\%), ethyl alcohol (VETEC, 99.5\%), carbon dioxide (White Martins, 99.99\%), tween 80 (Dynamic). To ensure the growth conditions of microorganisms, water, culture medium, and/or substrates, as well as glassware and laboratory utensils, were sterilized for $20 \mathrm{~min}$. in an autoclave at $121{ }^{\circ} \mathrm{C}$ (Autoclave vertical Phoenix luferco).

\section{Fungal isolates}

Four fungal isolates, Penicillium sp. F04, Aspergillus niger (F16), Aspergillus sp. F18, Aspergillus sp. F21 were kindly provided by the microbiological collection from the Microbiology sector of the Sanitation Laboratory at UFES (campus Vitória). These isolates were chosen based on previous studies [20, 21]. As presented, they show high lipase activity $-5.05 \pm 1.36 ; 2.32 \pm 0.39 ; 0.35 \pm 0.10$ and $1.18 \pm 0.98$, respectively.

The isolates were grown on PDA plates at $25^{\circ} \mathrm{C}$, for 7 days, to assess the mycelial mass for later use, that is, in submerged fermentation for enzyme production.

The Castellani method, 1967 [22] was used to prepare the fungi isolates stocks a preservation method that consists of placing five mycelium cubes of dimensions equal to $5 \times 5 \mathrm{~mm}$, in a $20 \mathrm{~mL}$ sterile flask, which, in its turn, contains $5 \mathrm{~mL}$ of distilled water, also sterilized.

\section{Morphological characterization}

The fungal isolates were first characterized by images taken directly from the medium dishes, with a $16 \mathrm{MP}$ and 5MP dual camera (Samsung, SM-A305GT) and without further preparation. The microscopic characterization, on the other hand, was done by a scanning electron microscope (SEM-JEOL1600LV). For the latter, the samples were fixed for $24 \mathrm{~h}$ in the Karnovisk solution (Glutaraldehyde $2 \%+$ Paraformaldehyde $2.5 \%$ in Sodium $0.1 \mathrm{M} \mathrm{pH}$ 7.2). Next, for the post-fixation step, they were washed in
Cacodilate buffer $(0.1 \mathrm{~mol} / \mathrm{L} ; \mathrm{pH} 7.2-7.4)$, in $1.25 \%$ potassium ferrocyanide solution and $1.0 \%$ buffered osmium tetroxide (Cacodilate $0.1 \mathrm{~mol} / \mathrm{L}$ ) at room temperature for $1 \mathrm{~h}$. Once the post-fixation step was done, the crusts were washed again with $0.1 \mathrm{M}$ cacodylate buffer.

Afterward, the samples were washed with cacodylate buffer solution and ultrapure water, followed by dehydration in different concentrations of ethanol. They were, then, taken to dry at a critical point (Autosandri-815, Tousimis), with subsequent gold coating in metallizer (Desk V, Denton Vaccum) for visualization in SEM. Images were taken using a $20 \mathrm{kV}$ tungsten filament.

\section{Standardization of optimum cultivation time}

The ideal cultivation time for higher enzymatic production was established through submerged cultivation in a shaker for 7 days. The growth curve, meanwhile, was outlined by removing daily aliquots of the liquid medium, while the extraction and dosage of lipases were conducted via standard curve of total proteins.

\section{Experimental design}

For optimization of lipase production, a complete factorial planning $3^{2}$ was used. This design is suitable for multifactorial experiments since it works by seeking a mutual relation amongst multiple factors to identify optimum conditions for processes [23-25]. Here, the variables studied were Temperature $\left({ }^{\circ} \mathrm{C}\right)$ and Inducer Concentration (\%), taking into consideration its influence on enzymatic production of fungal metabolism. These variables and the respective levels approached were defined according to a bibliographic survey, as shown in Table 1.

The statistical analysis of the planning of choice was performed using the software Statistica 12.0, trial version. The matrix with the complete factorial planning (of two variables and three levels) is shown in Table 2 below:

\section{Submerged phase cultivation}

In order to produce lipases from each of the four fungal isolates, a circle of approximately $5 \times 5 \mathrm{~mm}$ in diameter of the fungal colonywas inoculated with the aid of sterilized pipette tips in a $125 \mathrm{~mL}$ Erlenmeyer flaskcontaining $50 \mathrm{~mL}$ of minimum medium (MM). The $\mathrm{MM}$ consisted of $\mathrm{NaCl}\left(5.0 \mathrm{~g} \mathrm{~L}^{-1}\right), \mathrm{CaCl}_{2}\left(1.0 \mathrm{~g} \mathrm{~L}^{-1}\right)$ and soybean oil (inducer) emulsified with $0.1 \%$ Tween 80 in the vortex (Phoenix luferco) and added to each one of the assays. The

Table 1 Variables and parameters studied

\begin{tabular}{llr}
\hline Variables & Levels studied & References \\
\hline Temperature $\left({ }^{\circ} \mathrm{C}\right)$ & $25 ; 30 ; 37 ; 45$ & {$[26-31]$} \\
Inducer $(\%)$ & $1 ; 1,5 ; 2 ; 4 ; 8$ & {$[26,32-36]$} \\
\hline
\end{tabular}


Table 2 Factorial Planning Matrix $3^{2}$ for lipase production

\begin{tabular}{lll}
\hline Assay & Inducer (\%) & $\begin{array}{l}\text { Temperature } \\
\left({ }^{\circ} \mathbf{C}\right)\end{array}$ \\
\hline 1 & $2(-)$ & $28(-)$ \\
2 & $2(-)$ & $32(0)$ \\
3 & $2(-)$ & $36(+)$ \\
4 & $6(+)$ & $28(-)$ \\
5 & $6(+)$ & $32(0)$ \\
6 & $6(+)$ & $36(+)$ \\
7 & $10(0)$ & $28(-)$ \\
8 & $10(0)$ & $32(0)$ \\
9 & $10(0)$ & $36(+)$ \\
10 & $6(+)$ & $32(0)$ \\
11 & $6(+)$ & $32(0)$ \\
\hline
\end{tabular}

quantity of the inducer was defined according to the levels of the complete factorial planning. The flasks with enriched samples stirred at $110 \mathrm{rpm}$ in an orbital shaker incubator (Solab, SL233) for 6 days. The levels of the inducer and temperature evaluated are shown in Table 2.

\section{Extraction and dosage of lipases}

Following the previous step, the flasks were removed from the shaker and the sodium acetate buffer $(\mathrm{pH} 4.5)$ was added at a ratio of 10:1 (buffer: medium). Then they were both kept under stirring for $60 \mathrm{~min}$. The resulting content was filtered through filter paper (Unifil) and centrifuged at 15,000 rpm (Sigma) for $10 \mathrm{~min}$.

Ultraviolet absorption was the method employed to dose the total of proteins from the samples obtained in the previous steps. This procedure entailed pipetting the samples inside quartz cuvettes before running it through a spectrophotometer (Thermo Scientific, Genesys 10 UV Scanning) at $280 \mathrm{~nm}$ wavelength, according to Zaia et al. [37]. Five measurements of absorbance in different dilutions were made, all of them at wavelength equal to $280 \mathrm{~nm}$ to obtain the standard curve for protein dosing. The standard curve with BSA was then applied to the readings gathered from this step.

\section{Results and discussion \\ Morphological characterization}

The fungal isolates used in this work were obtained from grease boxes and soils in which oily residues were found
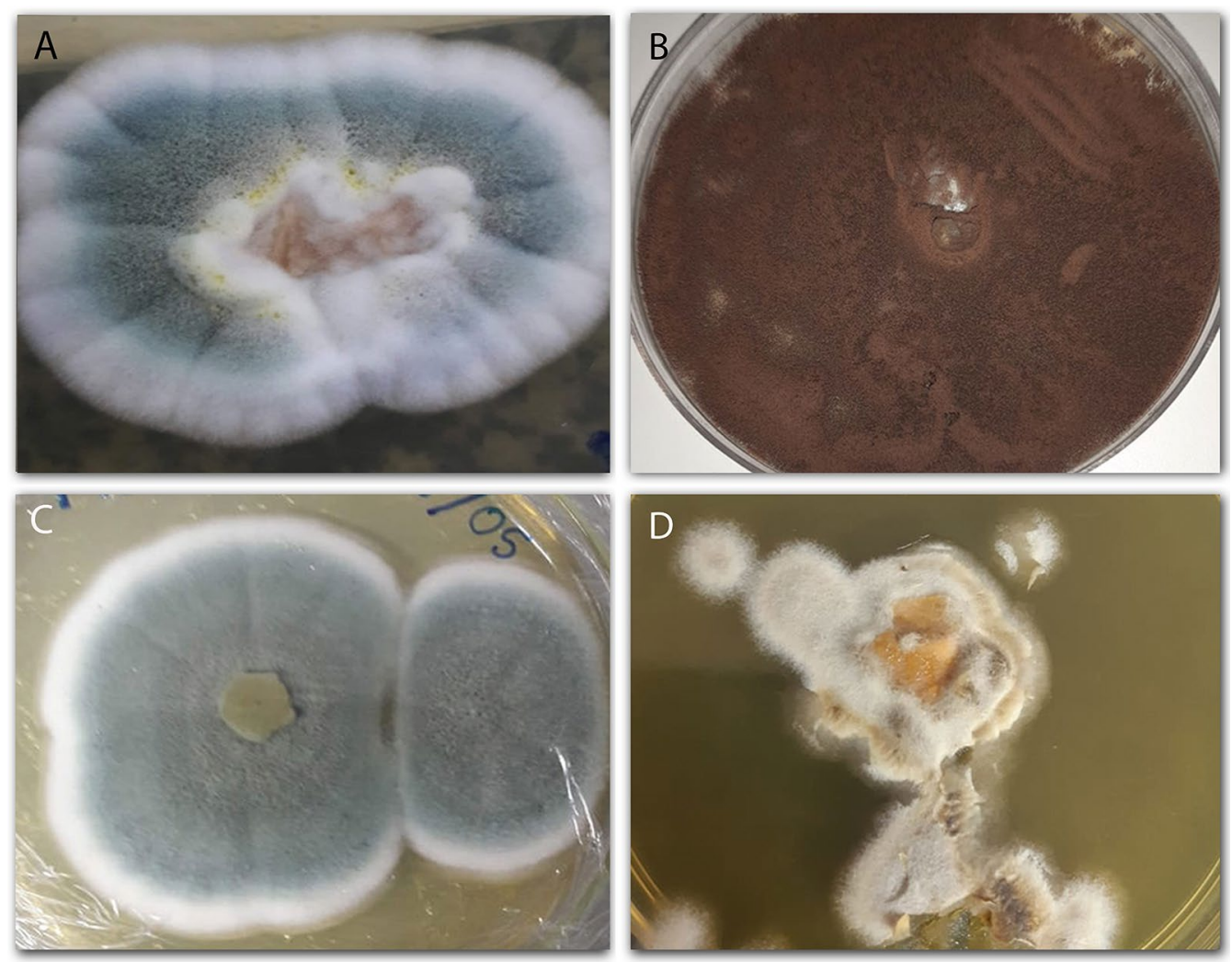

Fig. 1 Images obtained from low magnification for observation of the coloniesof Penicillium sp.F04 (A), Aspergillus niger F16 (B), Aspergillus sp. F18 (C), and Aspergillus sp. F21 (D) 

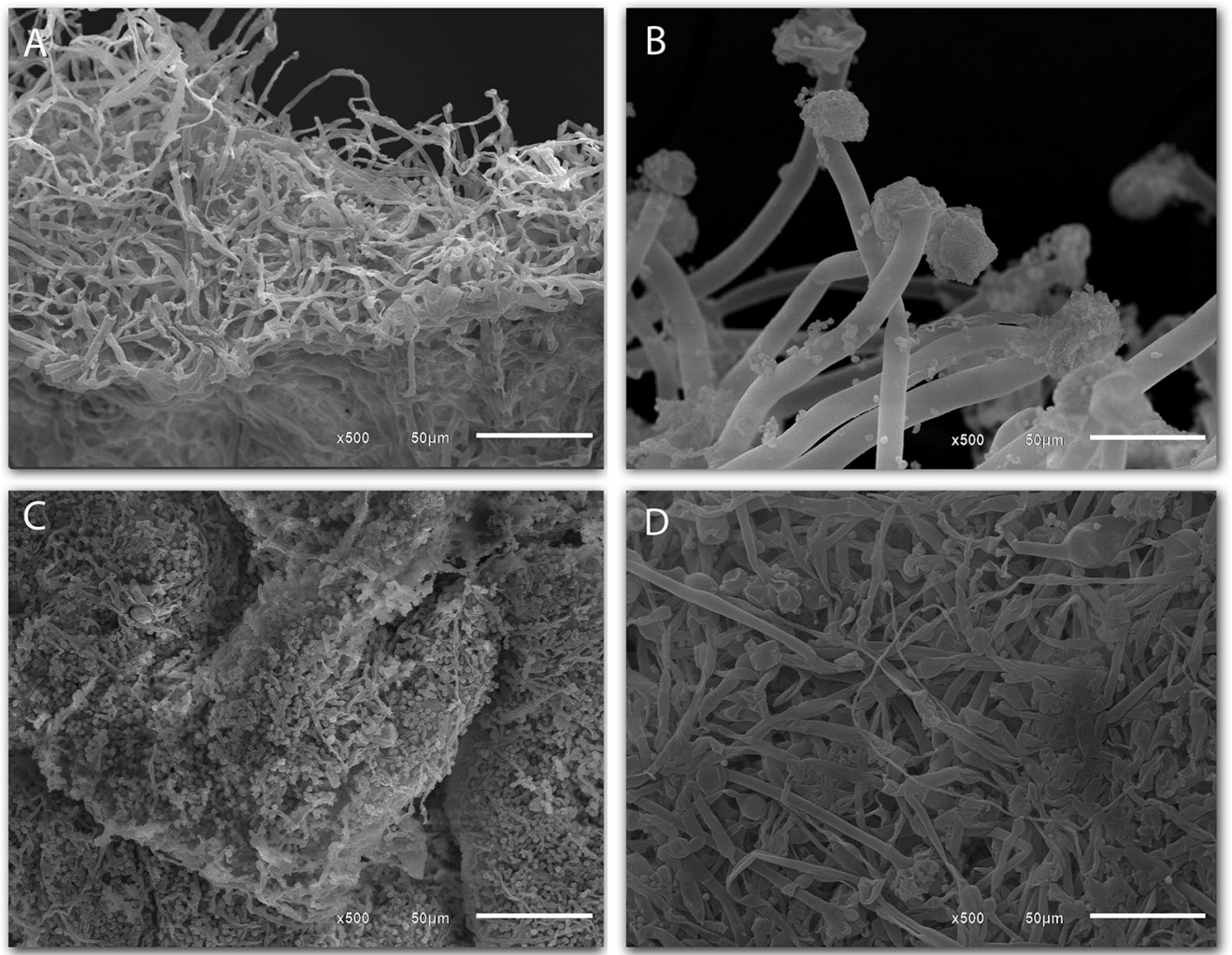

Fig. 2 Images obtained through scanning electron microscopy (SEM) to observe the microstructures of the fungalisolates: Penicillium sp. (A), Aspergillus niger (B), Aspergillus sp. (C), and Aspergillus sp. (D)

[20, 21]. The cultivation medium with the inducer (soybean oil) is selective since only organisms capable of metabolizing lipid as carbon and energy source grew on it. Growth and multiplication of microorganisms on any substrate is often considered as the first step towards its bioconversion. In Fig. 1 are the cultures of the four fungal isolates, and it is possible to observe both the appearance and the coloration of the agglomerated mycelia macroscopically. Also known as "sac fungi" due to the shape of their asci [38], the ascomycetes genera Penicillium and Aspergillus $[39,40]$ are represented by filamentous fungi
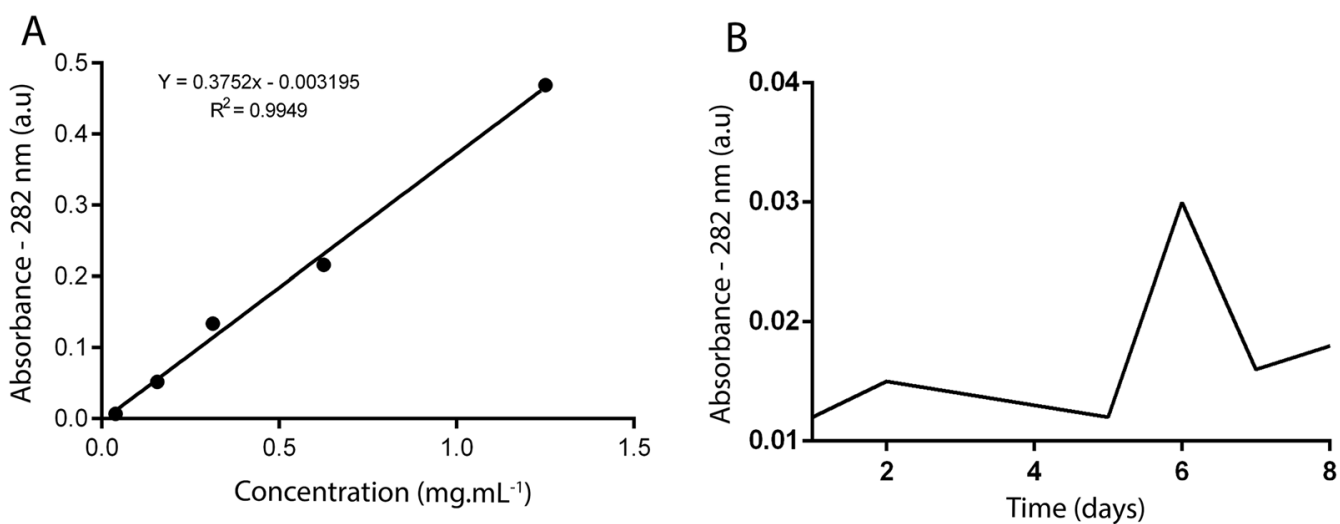

Fig. 3 Standard curve for total protein dosing, using BSA as protein model (A); Optimum time curve for production of lipases by Penicillium sp. F04 isolate (B) 
Table 3 Total Lipases obtained for each level from the Factorial Design Matrix $3^{2}$

\begin{tabular}{|c|c|c|c|c|c|c|}
\hline \multirow[t]{2}{*}{ Assay } & \multirow[t]{2}{*}{ Inducer (\%) } & \multirow[t]{2}{*}{ Temperature $\left({ }^{\circ} \mathrm{C}\right)$} & \multicolumn{4}{|c|}{ Total lipases $\left(\mu \mathrm{g} \mathrm{mL}^{-1}\right)$} \\
\hline & & & F04 & F16 & F18 & F21 \\
\hline 1 & 2 & 28 & 936.7 & 395.2 & 2290.2 & 2425.5 \\
\hline 2 & 2 & 32 & 2560.9 & 801.3 & $11,007.0$ & 4510.0 \\
\hline 3 & 2 & 36 & 2127.8 & 1613.4 & 4753.7 & 4320.5 \\
\hline 4 & 6 & 28 & 1965.3 & 720.1 & 1396.9 & 1099.1 \\
\hline 5 & 6 & 32 & 1586.4 & 1369.8 & 1586.4 & 3183.5 \\
\hline 6 & 6 & 36 & 7406.6 & 1451.0 & 1911.2 & 2019.5 \\
\hline 7 & 10 & 28 & 1830.0 & 1559.3 & 4022.7 & 1694.6 \\
\hline 8 & 10 & 32 & 2560.9 & 1532.2 & 2371.4 & 1396.8 \\
\hline 9 & 10 & 36 & 2209.0 & 1288.6 & 2209.0 & 1532.2 \\
\hline 10 & 6 & 32 & 1775.9 & 1310.5 & 2127.8 & 3156.5 \\
\hline 11 & 6 & 32 & 1770.0 & 1190.5 & 2019.5 & 3102.3 \\
\hline
\end{tabular}

that can be found in air, soil, vegetation, and indoor environments [41, 42].

On the other hand, the microscopic analysis of the isolates in this work was done by scanning electron microscopy, where it is possible to observe the fungal cells ultra-structures, presented in Fig. 2. Image A shown the Penicillium sp. F04 hyphae, whereas image B clearly shows the conidiophores and conidia of Aspergillus niger F16. According to Cruz [43], this last one species has globular, warty, and finely wrinkled conidia. Image $C$, in its turn, presents Aspergillus sp. F18 hyphae, and image D shows both the hyphae and conidia of the Aspergillus sp. F21. When making microscopic analysis of Penicillium species, the septate hyphae are observed. These oftenanastomosed hyphae have walls devoid of pigmentation [44]. As for their conidiophores, they appear as branches of the mycelium and are mostly perpendicular to the substrate. Additionally, they are composed of a stipe that can present itself as narrow or broad [45].

\section{Standardization of optimal cultivation time}

Determining the optimal cultivation time for enzyme production is an important study parameter because time has a direct impact on lipase production as well as process costs. For this, the growth curve based on the lipases production was determined. The BSA protein is frequently used as standard for protein quantification deriving from cellular metabolism [46]. As such, Fig. 3A shows the results of the curve and the regression equation used for the quantification of total lipases. In order to establish the optimal cultivation time, a growth curve was performed-as described in Sect. 2.2.3 of the methodology-, using the isolate Penicillium sp. F04 as study model. Results show that the optimal time for the enzymatic production is 6 days, with production starting on the fifth day, as indicated in Fig. 3B.
Cola et al. [47] obtained 3 to 4 days for the ideal time were using Aspergillus as study model to investigate the optimization of its lipase production. Kempka et al. [26], however, when optimizing the production of Penicillium verrucosum lipases, adopted 7 days for fermentation time. This divergence can be attributed to the varieties of each fungal isolate and conditions handled in their work, as well as the medium or inducers used on the different approaches.

\section{Total lipases}

Factorial planning is a widely used technique when two or more independent variables (factors) are investigated. It allows a combination of all variables at all levels, thus obtaining an analysis of a single variable, subject to all combinations from the others. [48]. For assessment of the effects of each studied variables and levels-namely, temperature $\left(28^{\circ} \mathrm{C}, 32{ }^{\circ} \mathrm{C}\right.$ and $\left.36^{\circ} \mathrm{C}\right)$ and inducer concentration $(2 \%, 6 \%$, and $10 \%)-$, the response variable used was total protein dosage according to the standard curve (Fig. 3A). The results for each experiment are presented in Table 3.

\section{Statistical analysis}

The analysis of variance (ANOVA) was done with the software Statistica 12.0 trial version, with significance level at 5\%, as shown in Table 4. The interactions between variables were also analyzed, being them: Linear interaction (L) or of the first order, and quadratic interaction (Q) or second order. The significant variables are shown in bold.

For better visualization of both outcome and significance of the study, Figs. 4, 5, 6 and 7 follow the same logical sequence of the results attainment with the graph of 
Table 4 ANOVA results for each fungal isolate analyzed: Penicillium sp. F04), Aspergillus niger F16, (Aspergillus sp. F18) and (Aspergillus sp. F21)

\begin{tabular}{|c|c|c|c|c|c|}
\hline & $\mathrm{SQ}^{*}$ & $D f^{*}$ & MS* & $\mathrm{F}^{*}$ & $\mathbf{p}^{*}$ \\
\hline \multicolumn{6}{|l|}{ Penicillium sp. F04 } \\
\hline (1) Indutor (\%) (L) & 158,275 & 1 & 158,275 & 13.6338 & 0.066152 \\
\hline Indutor (\%) (Q) & $6,443,756$ & 1 & $6,443,756$ & 555.0654 & 0.001797 \\
\hline (2) Temperatura $\left({ }^{\circ} \mathrm{C}\right)(\mathrm{L})$ & $8,193,288$ & 1 & $8,193,288$ & 705.7702 & 0.001414 \\
\hline Temperatura $\left({ }^{\circ} \mathrm{C}\right)(\mathrm{Q})$ & 515,061 & 1 & 515,061 & 44.3674 & 0.021805 \\
\hline $1 \mathrm{~L}$ by $2 \mathrm{~L}$ & 164,877 & 1 & 164,877 & 14.2025 & 0.063751 \\
\hline $1 \mathrm{~L}$ by $2 \mathrm{Q}$ & 79,138 & 1 & 79,138 & 6.8169 & 0.120703 \\
\hline $1 \mathrm{Q}$ by $2 \mathrm{~L}$ & $7,226,888$ & 1 & $7,226,888$ & 622.5244 & 0.001603 \\
\hline $1 \mathrm{Q}$ by $2 \mathrm{Q}$ & $8,930,000$ & 1 & $8,930,000$ & 769.2306 & 0.001297 \\
\hline Error & 23,218 & 2 & 11,609 & & \\
\hline Total SS & $29,321,982$ & 10 & & & \\
\hline \multicolumn{6}{|l|}{ Aspergillus niger F16 } \\
\hline (1) Inducer (\%) (L) & 410,921 & 1 & $410,921.3$ & 18.48341 & 0.007721 \\
\hline Inducer (\%) (Q) & 213 & 1 & 212.7 & 0.00957 & 0.925880 \\
\hline (2) Temperature $\left({ }^{\circ} \mathrm{C}\right)(\mathrm{L})$ & 469,504 & 1 & $469,504.4$ & 21.11850 & 0.005864 \\
\hline Temperature $\left({ }^{\circ} \mathrm{C}\right)(\mathrm{Q})$ & 13,146 & 1 & $13,146.2$ & 0.59132 & 0.476642 \\
\hline $1 \mathrm{~L}$ by $2 \mathrm{~L}$ & 554,206 & 1 & $554,205.8$ & 24.92840 & 0.004130 \\
\hline Error & 111,160 & 5 & $22,231.9$ & & \\
\hline Total SS & $1,559,213$ & 10 & & & \\
\hline \multicolumn{6}{|l|}{ Aspergillus sp. F18 } \\
\hline (1) Inducer (\%) (L) & $14,876,821$ & 1 & $14,876,821$ & 181.2705 & 0.005471 \\
\hline Inducer (\%) (Q) & $17,148,068$ & 1 & $17,148,068$ & 208.9451 & 0.004752 \\
\hline (2) Temperature $\left({ }^{\circ} \mathrm{C}\right)(\mathrm{L})$ & 225,855 & 1 & 225,855 & 2.7520 & 0.238998 \\
\hline Temperature $\left({ }^{\circ} \mathrm{C}\right)(\mathrm{Q})$ & $12,774,514$ & 1 & $12,774,514$ & 155.6544 & 0.006363 \\
\hline $1 \mathrm{~L}$ by $2 \mathrm{~L}$ & $4,573,610$ & 1 & $4,573,610$ & 55.7283 & 0.017475 \\
\hline $1 \mathrm{~L}$ by $2 \mathrm{Q}$ & $22,574,890$ & 1 & $22,574,890$ & 275.0696 & 0.003616 \\
\hline $1 \mathrm{Q}$ by $2 \mathrm{~L}$ & 11,957 & 1 & 11,957 & 0.1457 & 0.739419 \\
\hline $1 \mathrm{Q}$ by $2 \mathrm{Q}$ & $6,120,944$ & 1 & $6,120,944$ & 74.5822 & 0.013144 \\
\hline Error & 164,139 & 2 & 82,070 & & \\
\hline Total SS & $76,573,189$ & 10 & & & \\
\hline \multicolumn{6}{|l|}{ Aspergillus sp. F21 } \\
\hline (1) Inducer (\%) (L) & $7,331,455$ & 1 & $7,331,455$ & 4287.367 & 0.000233 \\
\hline Inducer (\%) (Q) & 730,825 & 1 & 730,825 & 427.380 & 0.002332 \\
\hline (2) Temperature $\left({ }^{\circ} \mathrm{C}\right)(\mathrm{L})$ & $1,173,068$ & 1 & $1,173,068$ & 685.999 & 0.001455 \\
\hline Temperature $\left({ }^{\circ} \mathrm{C}\right)(\mathrm{Q})$ & $1,641,584$ & 1 & $1,641,584$ & 959.983 & 0.001040 \\
\hline $1 \mathrm{~L}$ by $2 \mathrm{~L}$ & $1,058,224$ & 1 & $1,058,224$ & 618.839 & 0.001612 \\
\hline $1 \mathrm{~L}$ by $2 \mathrm{Q}$ & 610,744 & 1 & 610,744 & 357.158 & 0.002788 \\
\hline $1 \mathrm{Q}$ by $2 \mathrm{~L}$ & 976 & 1 & 976 & 0.571 & 0.528886 \\
\hline $1 \mathrm{Q}$ by $2 \mathrm{Q}$ & 803,516 & 1 & 803,516 & 469.889 & 0.002121 \\
\hline Error & 3420 & 2 & 1710 & & \\
\hline Total SS & $7,331,455$ & 1 & $7,331,455$ & 4287.367 & 0.000233 \\
\hline
\end{tabular}

the response surface (A), showing the influence of the two variables and their levels on the response variable (i.e. total lipases); the Pareto chart (B) where the effects of each variable and their first (L) and second (Q) order interactions are shown; the graphs of the individual influences of each variable, that is, temperature $(C)$ and the inducer concentration (D).

Submerged fermentation of the Penicillium sp. F04 can achieve a higher yield of total lipases if the conditions of $36{ }^{\circ} \mathrm{C}$ and $6 \%$ of inducer in the medium are met. Figure 4 depicts this relation. The two variables studied were 


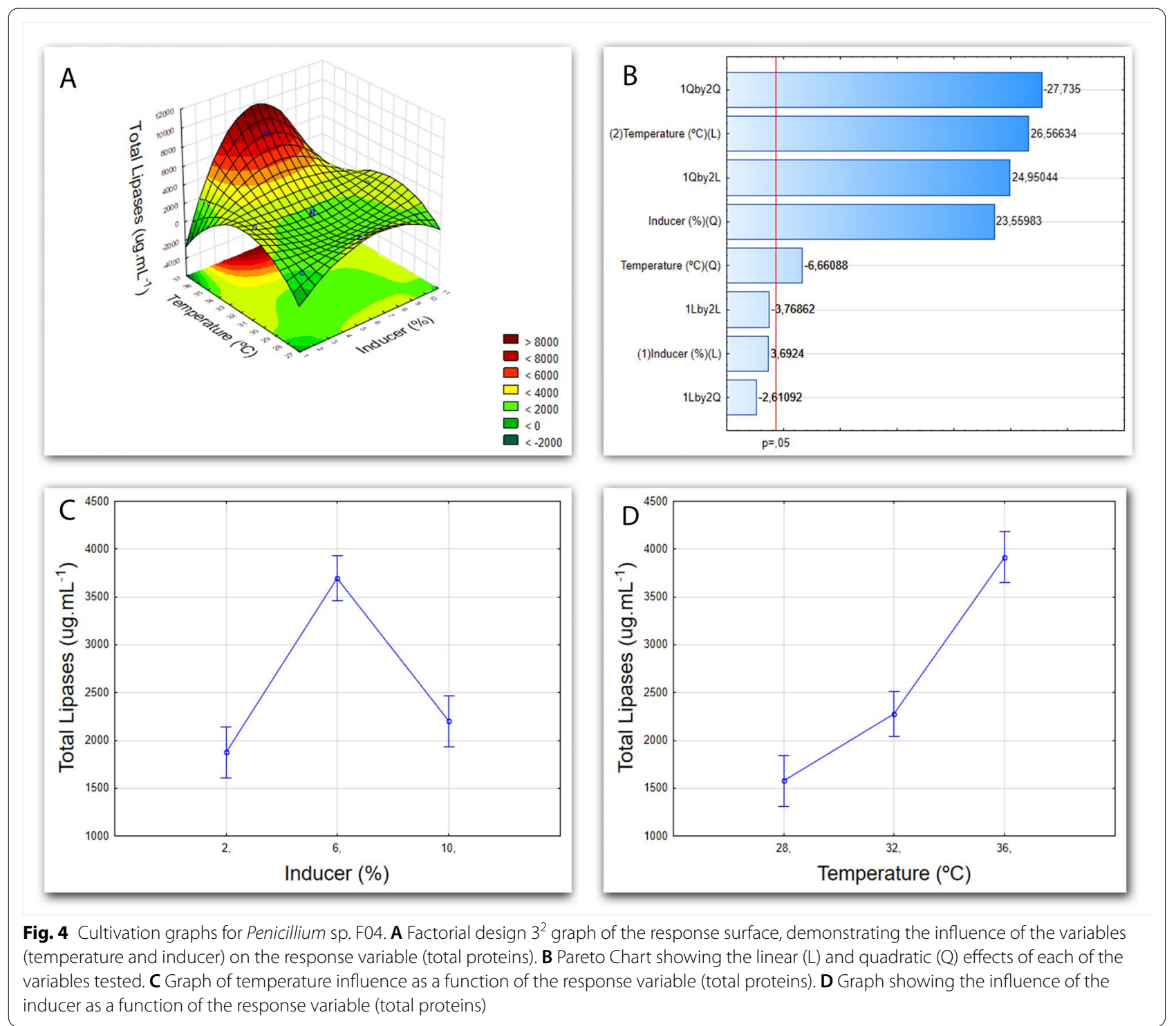

significant, and the effects are shown in the Pareto Chart (Fig. 4B). A closer look at the individual effects reveals that the best concentration for the inducer is 6\% (Fig. 4C) and that the increase of lipases in the medium matches the increase in temperature (Fig. 4D).

Salwoom et al. [49], isolated, characterized, and produced lipases from Pseudomonas cultures from Antarctica. In their work, results concerning temperature associate higher lipase yield to cultivation at $10{ }^{\circ} \mathrm{C}-$ contrary to what is observed here. This dissonance can be explained by the difference of microorganisms employed in the respective studies. Ideal conditions, along with specificities, vary depending on the individual metabolism and its natural habitat. Due to these variations, production optimization is an element of great importance in regards to industrial-scale yield.
Gutarra [50], used grains of babassu cake as a supplement to the liquid medium for cultivation and production of lipases by Penicillium simplicissium. However, the level of lipases was higher in the semi-synthetic medium, as the nutrients were readily available in it.

Figure 5 presents the graphs for the results obtained from the factorial design $3^{2}$ of the Aspergillus niger F16. Results reveal that not only both the highest temperature and inducer levels, $36^{\circ} \mathrm{C}$ and $10 \%$, are more significant for lipase production in this fugal isolate, which the response surface graph in image A demonstrate, but also that the temperature influence is greater than the inducer $(p=0.5)$ in submerged fermentation of $A$. niger F16, as indicated by the Pareto Chart in image B. Each variable can be separately analyzed in images $\mathrm{C}$ and $\mathrm{D}$. 


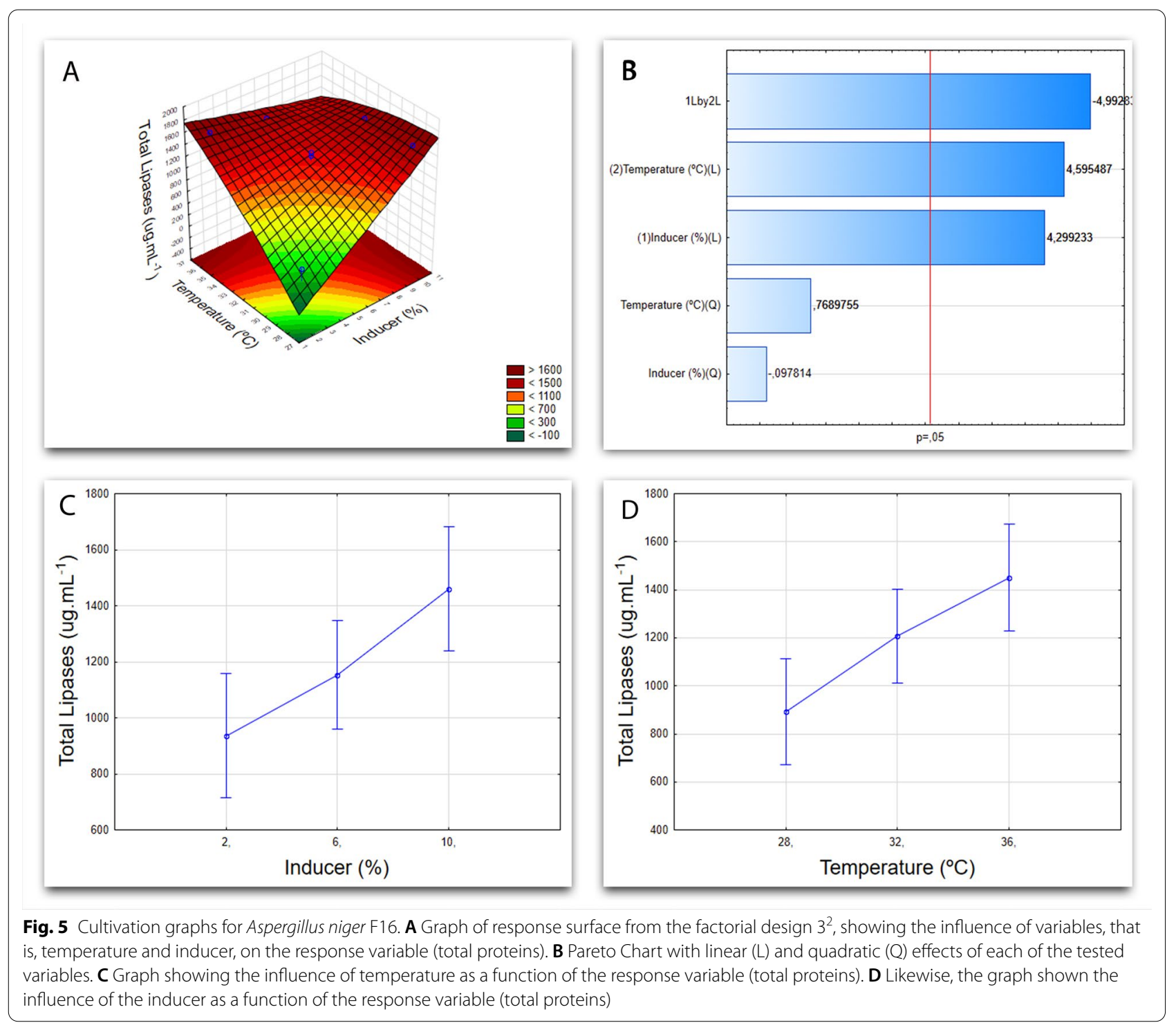

Research carried out with Aspergillus westerdijkiae [51] and Aspergillus niger [52] show that the yield of lipases produced is superior when an oily inducer is present in the medium, serving as a carbon source. Oliveira, et al. [53], when optimizing the production of Aspergillus ibericus lipases by fermentation in a solidstate, observed that the presence of $10.2 \%$ of lipids in the substrate was the ideal condition for achieving maximum lipase yield, similarly to the result obtained here in submerged fermentation for Aspergillus niger F16, which can be seen in Fig. 6 .

Moreover, Colla et al. [27] studied the production of lipases by submerged fermentation and in the solid-state for both Aspergillus flavus and Aspergillus niger and found $37{ }^{\circ} \mathrm{C}$ as the ideal temperature for enzyme production in submerged fermentation, coming close to the result obtained in this work. They also described that the enzymes produced by submerged fermentation were more stable to temperature than those acquired by fermentation in a solid-state.

The best result achieved for lipase production from the Aspergillus sp. F18 designates as ideal conditions $32{ }^{\circ} \mathrm{C}$ for temperature and $2 \%$ of inducer concentration in the medium, which can be seen in Fig. 6A by the graph of surface response, demonstrating the interaction between variables and both of their levels. Figure $6 \mathrm{C}$ and $\mathrm{D}$, on the other hand, exhibit each variable alone. As for Fig. 6B, the Pareto Chart is on shown, in which is possible to visualize greater influence of the inducer rather than temperature $(p=0.5)$ for submerged fermentation of Aspergillus sp. F18, the inducer also being more significant than the 


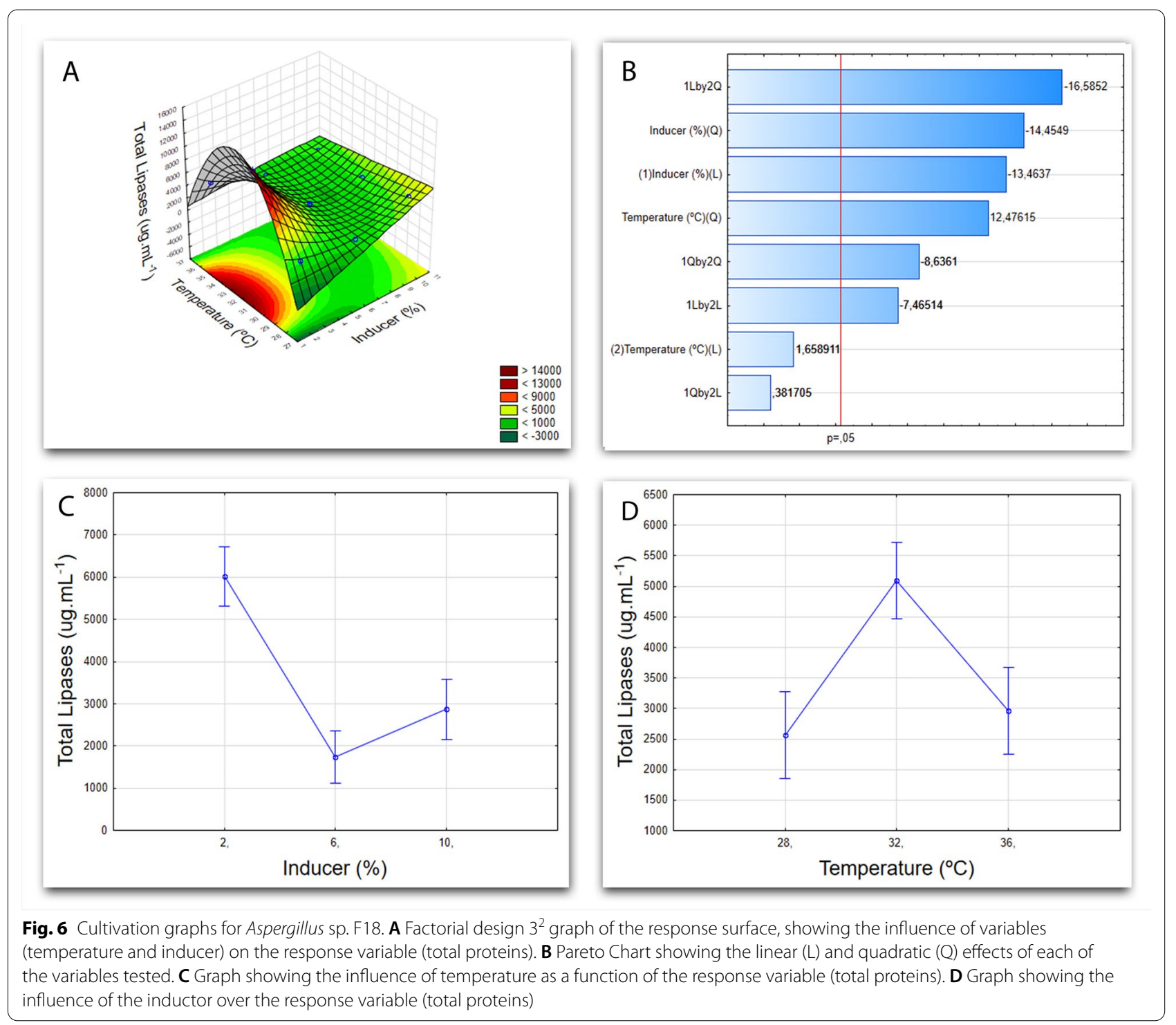

temperature to produce lipases when it comes to this isolate.

Similarly, another study conducted by Das et al. [32] using Aspergillus sp. sought to maximize Aspergillus tamarii lipase yield by optimizing the nutritional conditions of the submerged fermentation process. They found that mediums in which coconut oil $(2.5 \%, \mathrm{v} / \mathrm{v})$ were added achieved maximal lipase production, which is close to the results observed in the present research. Sethi et al. [28], produced Aspergillus terreus lipases using oily substrates in the culture medium, with the temperature at $30^{\circ} \mathrm{C}$.

And so, in Fig. 7A, the graph of surface response presents the interaction of variables, demonstrating which levels of the factors were more significant for lipase production on Aspergillus sp. F21 isolates: $32{ }^{\circ} \mathrm{C}$ for temperature and $2 \%$ of inducer. It is also possible to analyze each variable separately in Fig. 7C, D. Figure 7B shows the Pareto Chart for the variables, in which the greater influence of the inducer, instead of the temperature $(p=0.5)$, in the submerged fermentation of Aspergillus sp. F21 is evident. In this case, a lower inducer percentage leads to higher lipase yield, when temperature is average.

Now, research about the optimization of conditions of submerged fermentation for different microorganisms revealed that having $3 \%$ coconut oil in the medium, as well temperature at $30^{\circ} \mathrm{C}$, for 5 days, resulted in the highest lipase yield in Aspergillus flavus [54]. These very same conditions are close to the results obtained in this work, which is being shown in Fig. 7 and can be explained by both the different mediums and inducers used, in addition to the specificity of each microorganism. Rajan et al. [33], in a comparative study 


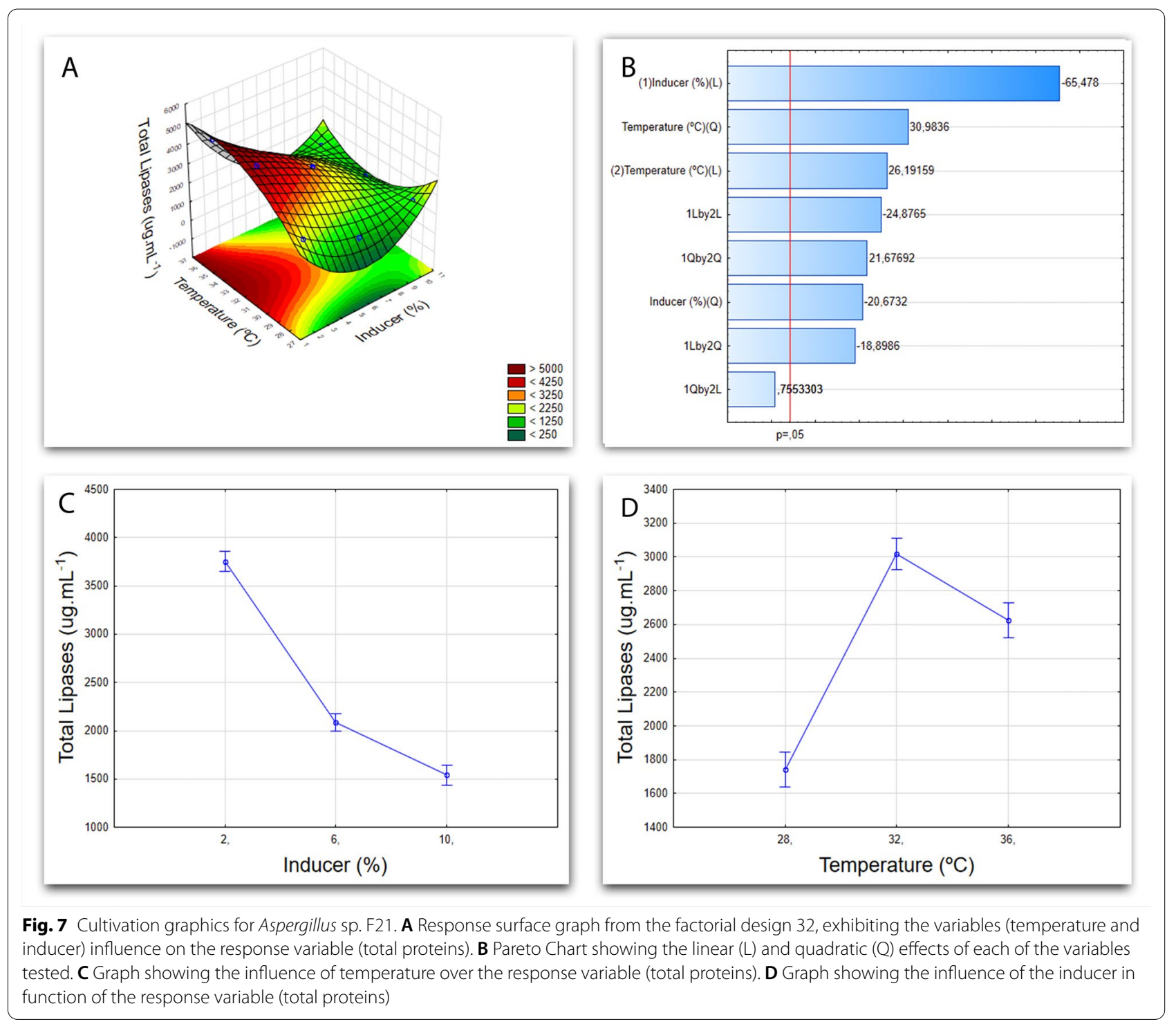

of submerged fermentation and solid-state fermentation for production of alkaline lipase, submitted Aspergillus fumigatus to submerged cultivation at $30{ }^{\circ} \mathrm{C}$ with $1 \%$ of olive oil in the medium. These values are close to the ideal levels for Aspergillus sp. F21 found here. Also, the yield achieved was 550,90 U.

In general, it appears that, for the variables evaluated here (temperature and concentration of the inducer), each isolate responds in a different way. However, these variables proved to be statistically significant for the experiments performed with all four fungal isolates, thus showing that the levels assessed are indeed very relevant for the standardization and optimization of fungal lipase production. The highest temperature evaluated $\left(36^{\circ} \mathrm{C}\right)$ was the best condition for lipase production in isolates F04 and F16, whereas the average temperature $\left(32{ }^{\circ} \mathrm{C}\right)$ was the best for isolates $\mathrm{F} 18$ and F21. Regarding the concentration of the inducer, minimum value of $2 \%$ was ideal for isolates the F18 and F21, contrary to the others, that is, isolates F04 and F16, in which 6 and 10\%, respectively, of the inducer concentration, were the optimum conditions.

\section{Conclusion}

The results showed that the fungi obtained in this work can be a promising and sustainable alternative to produce lipases on a large scale. The factorial design using the variables temperature and concentration of the inducer enabled the optimization of lipases production. Yet, among the fungi isolates used in this study, the one which presented the greatest lipase yield was 
Aspergillus sp. F18, with $11,007\left(\mu \mathrm{g} \mathrm{mL} L^{-1}\right)$ at $32{ }^{\circ} \mathrm{C}$ and $2 \%$ of the inducer as cultivation conditions.

\section{Statement of novelty}

Oily residues from environmental sanitation are considered one of the main problems for wastewater treatment plants. In these residues are found several wild microorganisms adapted to lipid metabolism. In this work, we evaluate the potential of these microorganisms in the production of enzymes (lipases) that are widely demanded in the industry.

\section{Acknowledgements}

This work used the equipment facilities at the Laboratory of Cellular Ultrastructure Carlos Alberto Redins and Laboratory of Sanitation (LABSAN), with thanks for providing the equipment and technical support for experiments.

\section{Authors' information}

Not applicable.

\section{Authors' contributions}

LMC and JPO conceived the project. LMC, GPP and RFSP performed the experiments, characterizations, and analysis. LMC, JPO, EF, ASX and STAC contributed to discussions and writing of the manuscript. JPO guided the research. All authors read and approved the final manuscript.All authors read and approved the final manuscript.

\section{Funding}

This work had financial support from the Brazilian Ministry of Science and Technology (CNPq Grant 28/2018) and the Foundation Support Research and Innovation of Espírito Santo (Grants 21/2018 and 01/2019).

\section{Availability of data and materials}

The datasets used and/or analyzed during the current study are available from the corresponding author on reasonable request.

\section{Declarations}

Ethics approval and consent to participate

Not applicable.

\section{Consent for publication}

Not applicable.

\section{Competing interests}

The authors declare that they have no competing interests.

\section{Author details}

${ }^{1}$ Federal University of Espírito Santo, Alto Universitário, S/N Guararema, Alegre, ES 29500-000, Brazil. ${ }^{2}$ Federal University of Espírito Santo, Av. Fernando Ferrari 514, Vitória, ES 29075-910, Brazil. ${ }^{3}$ Federal University of Espírito Santo, Av. Marechal Campos1468, Vitória, ES 29040-090, Brazil.

Received: 28 May 2021 Accepted: 29 October 2021

Published online: 10 November 2021

\section{References}

1. Gonçalves CCS, Marsaioli AJ. Facts and trends of biocatalysis. Quim Nova. 2013:36:1587-90.
2. Alcalde M, Ferrer M, Plou FJ, Ballesteros A. Environmental biocatalysis: from remediation with enzymes to novel green processes. Trends Biotechnol. 2006. https://doi.org/10.1016/j.tibtech.2006.04.002.

3. Jegannathan KR, Nielsen PH. Environmental assessment of enzyme use in industrial production - a literature review. J Clean Prod. 2013. https://doi. org/10.1016/j.jclepro.2012.11.005

4. Jaeger KE, Eggert T. Lipases for biotechnology. Curr Opin Biotechnol. 2002. https://doi.org/10.1016/S0958-1669(02)00341-5.

5. Sharma R, Chisti Y, Banerjee UC. Production, purification, characterization, and applications of lipases. Biotech Adv. 2001. https://doi.org/10.1016/ S0734-9750(01)00086-6.

6. Panda T, Gowrishankar BS. Production and applications of esterases. Appl Microbiol Biotechnol. 2005. https://doi.org/10.1007/s00253-004-1840-y.

7. Castro HF, Mendes AA, Santos JC, Aguiar CL. Modification of oils and fats by biotransformation. Quim Nova. 2004;27:146-56.

8. Kirk O, Borchert TV, Fuglsang CC. Industrial enzyme applications. Curr Opin Biotechnol. 2002. https://doi.org/10.1016/S0958-1669(02)00328-2.

9. Liu R, Jiang X, Mou H, Guan H, Wang H, Li X. A novel low-temperature resistant alkaline lipase from a soda lake fungus strain Fusarium solani N4-2 for detergent formulation. Biochem Eng. 2009. https://doi.org/10. 1016/j.bej.2009.05.016.

10. Hassan AH, Awad S, Prochasson P. The Swi2/Snf2 bromodomain is required for the displacement of SAGA and the octamer transfer of SAGAacetylated nucleosomes. J Biol Chem. 2006. https://doi.org/10.1074/jbc. M602851200.

11. Zimmer KR, Borré GL, Trentin DS, Júnior CW, Frasson AP, Graeff AA, Gomes P, Macedo AJ. Microbial enzymes for therapeutic use and clinical diagnosis. Revista Liberato. 2009;10:123-37.

12. Orlandelli RC, Specian V, Felber AC, Pamphile JA. Enzymes of industrial interest: production by fungi and applications. SaBios-Rev Saúde e Biol. 2012:7:97-109.

13. Nielsen J. Production of biopharmaceutical proteins by yeast: advances through metabolic. Bioengineered. 2013. https://doi.org/10.4161/bioe 22856

14. Casas-Godoy L, Gasteazoro F, Duquesne S, Bordes F, Marty A, Sandoval G. Lipases: an overview. Methods Mol Biol. 2018. https://doi.org/10. 1007/978-1-4939-8672-9_1.

15. Colen, G. Isolation and selection of filamentous fungi producing lipases. https://repositorio.ufmg.br/bitstream/1843/MAFB-72BGXL/1/ tese_g. colen.pdf (2006). Acessed 18 December 2020.

16. Pimentel, M.C.B. Production of lipases by filamentous fungi: kinetic studies and ester synthesis. http://repositorio.unicamp.br/bitstream/ REPOSIP/248943/1/Pimentel_MariadoCarmodeBarros_D.pdf (1996). Acessed 18 December 2020

17. Carvalho PO, Calafatti SA, Marassi M, Silva DM, Contesini FJ, Bizaco R, Macedo GA. Potential of enantioselective biocatalysis of microbial lipases. Quim Nova. 2005;28:614-6.

18. Hita H, Robles A, Camacho B, González PA, Esteban L, Jiménez MJ, Muñío MM, Molina E. Production of structured triacylglycerols by acidolysis catalyzed by lipases immobilized in a packed bed reactor. Biochem Eng J. 2009. https://doi.org/10.1016/j.bej.2009.05.015.

19. Liu W, Li M, Yan Y. Expressão e caracterização heterólogas de uma nova lipase de Pseudomonas fluorescens Pfo-1 e usada para produção de biodiesel. Sci Rep. 2017;7:15711.

20. Rodrigues, C. Seleção de fungos produtores de lipases a partir de resíduos oleosos derivados do saneamento ambiental. Tese (Doutorado em Engenharia Ambiental)_Centro Tecnológico, Universidade Federal do Espírito Santo. Vitória. 2011.

21. Curti, C. Pretreatment of microalgeous biomass using hydrolytic enzymes from fungal isolates. http://repositorio.ufes.br/handle/10/ 10992 (2019). Accessed 18 December 2020.

22. Castellani AA. Maintenance and cultivation of the common pathogenic fungi of man in sterile distilled water: further researches. J Trop Med Hyg. 1967;70:181-4.

23. Kaushik P, Malik A. Process optimization for efficient dye removal by Aspergillus lentulus FJ172995. J Hazard Mater. 2011. https://doi.org/10. 1016/j.jhazmat.2010.09.096.

24. Mathialagan T, Viraraghavan T. Biosorption of pentachlorophenol by fungal biomass from aqueous solutions: a factorial design analysis. Environ Technol. 2005. https://doi.org/10.1080/09593332608618542. 
25. Ponnusami V, Krithika V, Madhuram R, Srivastava SN. Biosorption of reactive dye using acid-treated rice husk: factorial design analysis. J Hazard Mater. 2007. https://doi.org/10.1016/j.jhazmat.2006.08.040.

26. Kempka AP, Lipke NL, Pinheiro T, Menoncin S, Treichel H, Freire DMG, Di Luccio M, Oliveira D. Response surface method to optimize the production and characterization of lipase from Penicillium verrucosum in solid-state fermentation. Bioprocess Biosyst Eng. 2008;31:119-25. https://doi.org/10.1007/s00449-007-0154-8.

27. Colla LM, Ficanha AMM, Rizzardi J, Bertolin TE, Reinehr CO, Costa JAV. Production and characterization of lipases by two new isolates of Aspergillus through solid-state and submerged fermentation. BioMed Res Int. 2015;2015:1-9. https://doi.org/10.1155/2015/725959.

28. Sethi BK, Rout JR, Das R, Nanda PK, Sahoo SL. Lipase production by Aspergillus terreus using mustard seed oil cake as a carbon source. Ann Microbiol. 2013. https://doi.org/10.1007/s13213-012-0467-y.

29. Sugihara A, Shimada Y, Takada N, Nagao T, Tominaga Y, Ferment J. Penicillium abeanum lipase: purification, characterization, and its use for docosahexaenoic acid enrichment of tuna oil. J Ferment Bioeng. 1996. https://doi.org/10.1016/S0922-338X(97)86991-7.

30. Godoy MG, Gutarra MLE, Maciel FM, Felix SP, Bevilaqua JV, Machado OLT, Freire DMG. Use of a low-cost methodology for biodetoxification of castor bean waste and lipase production. Enzyme Microb Technol. 2009. https://doi.org/10.1016/j.enzmictec.2009.01.002.

31. Miranda OA, Salgueiro AA, Pimentel MCB, Lima-Filho JL, Melo EHM, Duran N. Lipase production by a Brazilian strain of Penicillium citrinum using an industrial residue. Bioresour Technol. 1999;69:145-7. https:// doi.org/10.1016/S0960-8524(98)00166-7.

32. Das A, Bhattacharya S, Shivakumar S, Shakya S, Sogane SS. Coconut oil-induced production of a surfactant-compatible lipase from Aspergillus tamarii under submerged fermentation. J Basic Microbiol. 2016. https://doi.org/10.1002/jobm.201600478.

33. Rajan A, Nair AJ. A comparative study on alkaline lipase production by a newly isolated Aspergillus fumigatus MTCC 9657 in submerged and solid-state fermentation using an economically and industrially feasible substrate. Turk J Biol. 2011. https://doi.org/10.3906/biy-0912-6.

34. Yadav RP, Saxena RK, Gupta R, Davidson S. Lipase production by Aspergillus and Penicillium species. Folia Microbiol. 1998. https://doi.org/10. 1007/BF02818576.

35. Gombert AK, Pinto AL, Castilho LR, Freire DMG. Lipase production by Penicillium restrictum in solid-state fermentation using babassu oil cake as substrate. Process Biochem. 1999. https://doi.org/10.1016/S00329592(99)00036-9.

36. Utami TS, Hariyani I, Alamsyah G, Hermansyah H. Production of dry extract extracellular lipase from Aspergillus niger by solid-state fermentation method to catalyze biodiesel synthesis. Energy Procedia. 2017. https://doi.org/10.1016/j.egypro.2017.10.275.

37. Zaia DAM, Zaia CTBV, Lichtig J. Determination of total proteins via spectrophotometry: advantages and disadvantages of existing methods. Químia Nova. 1998;21:787-93.

38. Tortora GJ, Funker BR: Microbiology. Porto Alegre (2012).

39. Alexopoulos CJ, Mims CW, Blackwell M. Introductory mycology. New York: Wiley; 1996.

40. Houbraken J, Vries RP, Samson RA. Modern taxonomy of biotechnologically important Aspergillus and Penicillium species. Adv Appl Microbiol. 2014. https://doi.org/10.1016/B978-0-12-800262-9.00004-4.

41. Visagie CM, Houbraken J, Frisvad JC, Hong SB, Klaassen CHW, Perrone G. Identification and nomenclature of the genus Penicillium. http:// tede2.unicap.br:8080/handle/tede/997 (2014). Accessed 18 December 2020.

42. Samson RA, Visagie CM, Houbraken J, Hong SB, Hubka V, Klaassen CHW. Phylogeny, identification and nomenclature of the genus Aspergillus. http://repositorio.unicamp.br/bitstream/REPOSIP/321393/1/VonHe rtwig_AlineMorgan_M.pdf (2014). Accessed 18 December 2020.

43. Cruz R. Guide to laboratory diagnosis of invasive fungal disease by filamentous fungi. Revista Chilena Infectol. 2014. https://doi.org/10. 4067/S0716-10182014000200008.

44. Pitt J. A laboratory guide to common Penicillium species. Mycologia. 1991. https://doi.org/10.2307/3807483.

45. Silva LRC. Penicillium species in caatinga and Atlantic Forest soils, tanase production and detection of mycotoxigenic potential. https:// repositorio.ufpe.br/handle/123456789/12804 (2013). Accessed 18 December 2020

46. Lowry OH, Rosenbrough NJ, Farr RL, Randall RJ. Protein measurement with the Folin phenol reagent. J Biol Chem. 1951;193:265-75.

47. Colla LM, Primaz AL, Benedetti S, Loss RA, de Lima M, Reinehr CO, Costa JAV. Surface response methodology for the optimization of lipase production under submerged fermentation by filamentous fungi. Braz J Microbiol. 2016. https://doi.org/10.1016/j.bjm.2016.01.028.

48. Bruns RE, Scarminio IS, Neto BB. How to experiment: applications in science and industry. São Paulo (2010)

49. Salwoom L, Raja-Abd-Rahman RNZ, Salleh AB. Isolation, characterization and production of lipase of a bacterial strain adapted to cold Pseudomonas sp. LSK25 isolated from the island of Signy in Antarctica. Moléculas. 2019;24:715.

50. Gutarra KLE, Godoy MG, Silva JN, Guedes IA, Lins U, Castilho LR, Freire DMG. Lipase production and Penicillium simplicissimum morphology in solid-state and submerged fermentation. Biotechnol J. 2009. https:// doi.org/10.1002/biot.200800298.

51. Castro FF, Pinheiro ABP, Nassur CB, Barbosa-Tessmann IP. Myceliumbound lipase from a locally isolated strain of Aspergillus westerdijkiae. Biocatal Agric Biotechnol. 2017. https://doi.org/10.1016/j.bcab.2017.04. 009.

52. Colin VL, Baigorí MD, Pera LM. Mycelium-bound lipase production from Aspergillus niger MYA 135, and its potential applications for the transesterification of ethanol. J Basic Microbiol. 2011. https://doi.org/10.1002/ jobm.201000232.

53. Oliveira F, Salgado JM, Abrunhosa L, Pérez-Rodríguez N, Domínguez JM, Venâncio A, Belo I. Optimization of lipase production by solid-state fermentation of olive pomace: from flask to laboratory-scale packedbed bioreactor. Bioprocess Biosyst Eng. 2017. https://doi.org/10.1007/ s00449-017-1774-2.

54. Padhiar J, Das A, Bhattacharya S. Optimization of process parameters influencing the submerged fermentation of extracellular lipases from Pseudomonas aeruginosa, Candida albicans, and Aspergillus favus. Pak J Biol Sci. 2011;14:1011-8.

\section{Publisher's Note}

Springer Nature remains neutral with regard to jurisdictional claims in published maps and institutional affiliations.

Ready to submit your research? Choose BMC and benefit from

- fast, convenient online submission

- thorough peer review by experienced researchers in your field

- rapid publication on acceptance

- support for research data, including large and complex data types

- gold Open Access which fosters wider collaboration and increased citations

- maximum visibility for your research: over $100 \mathrm{M}$ website views per year

At BMC, research is always in progress.

Learn more biomedcentral.com/submissions 